\title{
Que esta vida sea digna
}

\section{Guadalupe Santa Cruz ${ }^{1}$}

Lo que impacta y vuelve a impactar es el tabú que envuelve al aborto en los discursos públicos en Chile, el modo en que ese silencio -silencio a gritos- le da la espalda a una realidad y la convierte, por el mismo hecho de no darle lugar, en sórdida.

Aunque, desde la fijeza de las posiciones moralizantes, este silencio es por sobre todo un rechazo a abrir el debate, porque de cuando en cuando circulan imágenes cargadas -de pocas palabras pero intenso sentido- que se presentan como afirmaciones irrebatibles en cuanto escamotean el fundamento que las sostiene, ${ }^{2}$ reduciendo el aborto a una opción a favor o en contra de "la" vida y asimilándolo, como señala Olga Grau, a un asesinato. Abrir un debate sobre el aborto sería precisamente problematizar la noción de vida en una reflexión que no se encuentre agarrotada, como hasta ahora, entre los preceptos morales de la Iglesia católica y los paradigmas de la ciencia. La reflexión bioética, por ejemplo, abre una discusión plural en torno a las definiciones de vida y a la noción de persona, ${ }^{3}$ así como otras aproximaciones epistemológicas ${ }^{4}$ proponen diferenciar la ética -que supone la existencia de sujetos, capaces de tomarse a sí mismos como objeto de reflexión- de la moral, que se basa en individuos, que estarían más bien adecuados al imaginario de la institución social (según la hermosa distinción de Miguel Bensayat, ${ }^{5}$ los sujetos serían expresión de lo nómade y los individuos metáfora de lo sedentario).

Subrayaría, por eso, las palabras de una mujer que relata las circunstancias en las cuales tomó la decisión de realizarse un aborto: "estaba terminando con mi vida pasada", ${ }^{6}$ y las de Patricia Karina Vergara Sánchez, en este dossier, cuyo anhelo es "que esta vida sea digna". En esta vida, proyectada por las mujeres a partir de una biografía, en el paisaje que la sostiene y el tejido de relaciones con que la construyen, el deseo de maternidad aparece como una decisión abierta y relativa, inscrita en el tiempo. De estos vaivenes hablan los relatos que leemos en esta publicación, 
recorridos truncos e intermitentes con la pareja, indeterminación de la propia vida, soledad, "sábana desteñida": momentos no propicios para un embarazo, y foco de lo debiera ser la discusión sobre el aborto, en las lúcidas sugerencias de Antonio Bascuñán.

Junto con la drástica penalización legal del aborto, el tutelaje por la Iglesia Católica y la hegemonía del pensamiento conservador, habría que preguntarse si en la palabra común no es esta misma posibilidad de que la maternidad sea una opción la que provoca un nudo ciego. Como si el hecho de que las mujeres amasen deseos que no están relacionados con el amor de madre despertara una conmoción vinculada al imaginario -o a la experimentación- del abandono que atraviesa a nuestra cultura, como lo propone Gloria Salazar. Tal vez por ello se omita que gran parte de los abortos sean decididos por mujeres que ya tienen hijos (así lo recuerda uno de los relatos incluidos en esta publicación), al apuntar hacia un posible y difuso malquerer en la figura de una madre que no desea ser madre.

Habría que vincular la amalgama entre mujer y madre con la sutil y solapada simbiosis que supone el modelo dominante de los vínculos filiales, que vive la individuación del otro o de la otra como pérdida, y que rechaza percibir a los miembros de una familia -en las diversas formas que ésta se da en nuestra sociedad-como sujetos cuya vocación es la autonomía y no la adscripción. ${ }^{7}$ Ambas constituyen vertientes de una misma posición que reduce toda alteridad y que dificulta la ciudadanía, ciudadanía sexual en el ámbito que aquí abordamos.

El silencio que oprime a esta realidad, entretanto, sigue llevando a mujeres a poner en riesgo su vida, castigándolas y marcándolas con los poderosos estigmas que ha construido nuestra cultura en proyección de sus propios temores y en la dificultad de abrir camino a un pensamiento laico ${ }^{8}$ basado en la ética.

\section{Notas}

1 Escritora.

2 He comentado en otros textos estas apariciones esporádicas de imágenes: ya sea el afiche del grupo llamado "pro-vida", colocado en los espacios -publicitarios- de la calle, con la figura evanescente de una mujer sobre fondo blanco, carente de toda condición 
("Blandas violencias", Revista de Crítica Cultural No21), o las sangrientas imágenes del "Reporte" sobre Aborto de la desaparecida revista -publicitaria- [Lat.33], que reemplazaba los posibles argumentos por compendios informativos: el collage entre cifras -amalgama de informaciones provenientes del Ministerio de Salud y de la Policía de Investigaciones de Chile o descontextualizadas de las investigaciones en que éstas fueran recogidas, en las cuales, muchas veces, son parte de una argumentación para la despenalización del aborto-, la enumeración de técnicas de aborto inducido y fragmentos de textos legales extractados de la Constitución Política, del Código Civil, del Código Penal y del Código Sanitario que se refieren a él ("Chile, lenguas transversales", en Construir el futuro. Aproximaciones a proyectos de país I, Tomás Moulián coord., LOM, 2002).

3 Sergio Zorrilla y Claudia Dides, "Bioética, Ética y Aborto", Centro de Investigaciones en Bioética y Salud Pública (CIBISAP), Foro Abierto de Salud y Derechos Sexuales y Reproductivos, Santiago, Mayo 2000.

4 "Maternidad, aborto y ética en el marco de los Derechos Humanos", Con-spirando, Corporación de Salud y Políticas Públicas (Corsaps), Instituto Chileno de Medicina Reproductiva (Icmer), Centro de Investigaciones en Bioética y Salud Pública (Cibisap), Santiago, 2002.

5 Citado en "Maternidad, aborto y ética en el marco de los Derechos Humanos", op. cit.

6 Gloria Salazar, "Factores psicosociales asociados a la experiencia del aborto voluntario. Un estudio exploratorio", Universidad Central de Venezuela, Caracas, 1990.

7 Este molde se repite, pienso, en el vínculo de afiliación que se exige, por otro lado, en el seno de las instituciones, laborales, partidarias, corporativas y otras.

8 Durante los años setenta, en el Quebec (donde el aborto está desde entonces despenalizado), tras la amenaza de excomunión que hiciera la Iglesia Católica a las mujeres que se practicaran un aborto, un importante grupo de mujeres artistas, escritoras e intelectuales se presentó públicamente ante las autoridades eclesiásticas pidiendo ser excomulgadas. 